\title{
ANALISIS LEARNING OBSTACLE PADA MATERI VOLUME LIMAS
}

\author{
Zeni Alif Sawitri ${ }^{1}$, Nyiayu Fahriza Fuadiah ${ }^{2}$ Tanzimah $^{3}$ \\ Universitas PGRI Palembang ${ }^{1,2,3}$ \\ nyiayufahriza@univpgri-palembang.ac.id ${ }^{2}$
}

\begin{abstract}
ABSTRAK
Penelitian ini bertujuan untuk mengetahui learning obstacle pada materi volume limas kelas VIII. Partisipan pada penelitian ini adalah siswa kelas VIII SMP Shailendra Palembang dan guru mata pelajaran matematika. Penelitian ini menggunakan metode kualitatif, identifikasi learning obstacle ini bagian dari tahap prosfektif yang ada pada didactical design reserach. Identifikasi learning obstcale pada penelitian ini didapat dari hasil analisis tes diagnostik, hasil wawancara guru dan hasil kajian RPP guru. Hasil dari penelitian ini didapat learning obstacle pada materi volume limas dari faktor epistemologis adalah sebagai berikut: (a) learning obstacle pada konsep perpangkatan; (b) learning obstacle pada konsep phytagoras; (c) learning obstacle pada konsep satuan luas dan volume; dan (d) learning obstacle pada konsep limas. Learning obstacle pada materi volume limas dari faktor didaktis adalah RPP guru mata pelajaran tidak mencerminkan kegiatan belajar-mengajar yang cocok untuk materi volume limas. Learning obstacle pada materi volume limas dari faktor ontogenik tidak ditemukan pada saat berlangsungnya proses penelitian.
\end{abstract}

Kata kunci : learning obstacle, phytagoras, volume limas

\begin{abstract}
The aim of this study is to identify the learning obstacle in the VIII grade pyramid volume material. The students of VIII grade SMP Shailendra Palembang and mathematics teachers participated in this study. This study uses qualitative methods, and the detection of learning barriers is part of the prospective stage of didactic design research. The identification of learning barriers in this research was based on the diagnostic test review, the results of the teacher interviews and the results of the teaching curriculum. The results of this study obtained learning obstacle on the material of pyramid volume from epistemological factors as follows: (a) learning obstacle in the concept of rank; (b) learning obstacle in Pythagorean concept; (c) learning obstacle on the concept of unit area and volume, and (d) learning obstacle in the concept of the pyramid. The learning obstacle in the material of pyramid volume from didactic factors is that the subject teacher lesson plans do not reflect teaching and learning activities that are suitable for the material of pyramid volume. Learning obstacle in the material of pyramid volume from ontogenic factors was not found during the research process.
\end{abstract}

Keywords : learning obstacle, phytagoras, pyramid volume 


\section{PENDAHULUAN}

Pendidikan matematika memiliki peran yang sangat penting karena matematika adalah ilmu dasar yang digunakan secara luas dalam berbagai bidang kehidupan, melalui pembelajaran matematika siswa diharapkan dapat menumbuhkan kemampuan berpikir kritis, logis, sistematis, cermat, efektif, dan efisien dalam memecahkan masalah (Istiani dan Hidayatulloh, 2017).

Salah satu cabang dari kajian dalam matematika adalah geometri. Materi geometri dalam matematika SMP meliputi garis, sudut, bangun datar, kesebangunan, bangun ruang, dan pythagoras (Cahyaningrum, 2015). Menurut (Blanco, 2001) lemahnya siswa dalam bidang geometri salah satunya ditunjukkan dengan ketidakmampuan siswa untuk mengenali bangun ruang sisi datar. ketidakmampuan pada bagian-bagian dalam geometri bisa berdampak pada ketidakmampuan bagian lain dalam geometri karena banyak pokok pembahasan dalam geometri yang saling berhubungan (Sholihah dan Afriansyah, 2017).

Ketidakmampuan inilah yang biasa disebut dengan hambatan belajar (learning obstacle), dalam praktiknya sehari-hari secara alami mengalami situasi hambatan belajar (Fuadiah dkk, 2017). Hambatan-hambatan (obstacles) tersebut menurut Brousseau (2002:86) dapat disebabkan oleh beberapa faktor, yaitu obstacle of ontogenic origin (kesiapan mental belajar siswa), obstacle of didactical origin (akibat sistem pendidikan) dan obstacle of epistemological origin (pengetahuan siswa yang memiliki konteks aplikasi yang terbatas). Menurut Suryadi (2016) terdapat tiga faktor penyebab hambatan belajar (learning obstacle) yaitu hambatan ontogeni (kesiapan mental belajar), didaktis (akibat pengajaran guru) dan epistemologi (pengetahuan siswa yang memiliki konteks aplikasi yang terbatas).

Pada faktor epistemologis yang dialami siswa, Sunarsi (2009) melakukan penelitian analisis kesulitan siswa menggunakan soal. Berdasarkan jawaban dari soal yang diberikan mengenai volume limas, siswa tidak teliti dalam membaca soal, sehingga siswa salah dalam mengerjakan soal yang diberikan oleh guru, siswa hanya menyingkat penulisan, dan siswa tidak paham dengan unsur-unsur limas. Penelitian yang serupa juga dilakukan oleh Cahyaningrum (2015) dan mendapatkan kesimpulan bahwa kesalahan siswa dalam materi volume limas adalah kesulitan dalam perhitungan, persentase kesulitan dalam perhitungan sebesar 44,8\%.

Berdasarkan hasil wawancara dengan guru mata pelajaran matematika di SMP Shailendra Palembang didapat suatu informasi bahwa siswa di sekolah tersebut mengalami hambatan belajar (learning obstacles) seperti halnya siswa banyak melakukan kesalahan dalam mengerjakan soal, ketika soal yang diberikan berbeda sedikit dari contoh soal yang diberikan maka siswa sudah kebingungan dalam menjawab soal tersebut. Apabila dilihat dari RPP yang sudah dibuat guru mata pelajaran aktifitas antara guru dan siswa sudah baik, guru sudah sangat mendukung siswa dalam proses pembelajaran. Sehingga, bisa disimpulkan apa yang menjadi penyebab siswa tersebut mengalami hambatan belajar.

Sejalan dengan faktor didaktis, Sarah, Suryadi dan Fatimah (2017) yang mengkaji ulang buku BSE kelas VIII, buku teks yang dikaji dalam penelitian ini ada 3 buku BSE kelas VIII dengan materi volume limas. Hasil dari analisis buku teks yang dilakukan didapat kemampuan berpikir yang diperlukan dalam konstruksi volume limas pada buku BSE kelas VIII ternyata tingkatannya lebih tinggi dibanding dengan kemampuan yang dimiliki siswa. Hal tersebut menunjukkan bahwa kegiatan konstruksi volume limas pada buku BSE kelas VIII kurang sesuai dengan 
perkembangan alami siswa. Dengan kata lain, proses konstruksi volume limas yang disajikan pada buku kurang sesuai dengan learning trajectory siswa.

Dilakukan juga analisis pada salah satu buku teks yang ada di pasaran, dari analisis yang dilakukan didapat bahwa dalam penyajian contoh soal, bisa dilihat pada Gambar 1 buku ini hanya memberikan dua contoh soal dan juga dalam pemberian contoh soal tersebut dimulai dari tipe contoh soal yang sulit baru diberikan contoh soal tipe yang mudah.

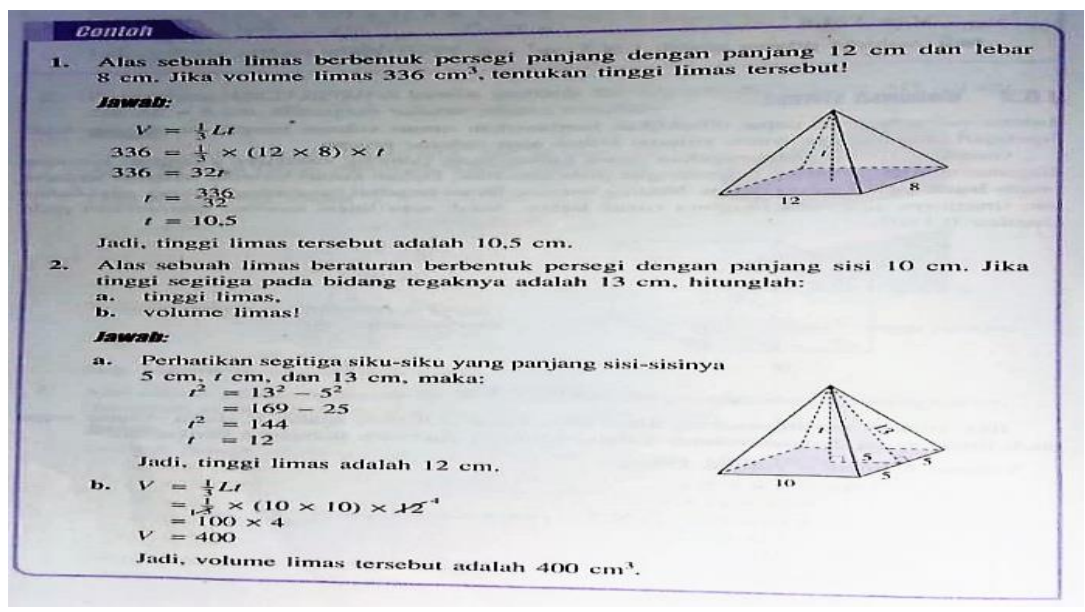

Gambar 1. Contoh soal volume limas

Peran buku teks dalam aktivitas kegiatan pembelajaran bukan hanya berperan sebagai sumber ajar yang menyediakan materi pembelajaran, tetapi bahkan berfungsi sebagai silabus (Mudzakir, 2010), guru pun sangat "setia" dengan buku teks meskipun guru menyadari siswa sulit memahami isi buku teks tersebut (Yunarti, 2017). Jadi bisa dipastikan guru akan mengikuti alur yang ada di dalam buku tersebut walaupun buku teks tersebut tidak sesuai dengan learning trajectory siswa, sehingga bisa saja tujuan dalam pembelajaran tersebut tidak akan tercapai.

Learning trajectory adalah suatu urutan dalam penyampaian materi yang sesuai dengan kemampuan berpikir siswa (Fauziah, 2016). Pengajuan learning trajectory dapat hanya berupa hipotesis, karena pengalaman guru membuat keputusan dan mengadaptasi aspek-aspek dari aktivitas yang direncanakan dalam respon adalah untuk membuktikan pemikiran dan belajar yang dilakukan siswa, perbedaan aspek dan tingkat pemahaman akan menjadi jelas terlihat bagi guru (Risnanosanti, 2012).

Learning obstacle dan learning trajectory inilah yang membuat seorang guru perlu menguasai materi ajar, dan memiliki pengetahuan lain yang terkait dengan siswa serta mampu menciptakan suatu desain didaktis yang dapat mendorong proses belajar secara optimal dan juga untuk meningkatkan pemahaman siswa, guru sering menggunakan konteks sehingga siswa dapat mensinergikannya dengan topik yang mereka pelajari (Fuadiah dkk, 2019). Dengan kata lain, seorang guru perlu memiliki kemampuan untuk menciptakan relasi didaktis (didactical relation) antara siswa dan materi ajar sehingga tercipta suatu situasi didaktis ideal bagi siswa (Suryadi, 2013).

Penelitian ini dilakukan bertujuan untuk mengetahui apa yang menjadi learning obstacle yang ditemukan pada materi volume limas yang diajarkan pada siswa kelas VIII. 


\section{METODE}

Penelitian ini menggunakan pendekatan kualitatif yang merupakan bagian dari didactical design research. Identifikasi learning obstacle merupakan bagian dari tahap analisis prosfektif dari didactical design researc. Waktu penelitian ini adalah semester genap tahun ajaran 2018/2019 di SMP Shailendra Palembang dengan partisipan pada penelitian ini adalah siswa kelas VIII SMP Shailendra Palembang. Objek pada penelitian ini adalah materi volume limas.

Hambatan-hambatan (obstacles) tersebut menurut Brousseau (2002:86) dapat disebabkan oleh beberapa faktor, yaitu obstacle of ontogenic origin (kesiapan mental belajar siswa), obstacle of didactical origin (akibat sistem pendidikan) dan obstacle of epistemological origin (pengetahuan siswa yang memiliki konteks aplikasi yang terbatas). Menurut Suryadi (2016) terdapat tiga faktor penyebab hambatan belajar (learning obstacle) yaitu hambatan ontogeni (kesiapan mental belajar), didaktis (akibat pengajaran guru) dan epistemologi (pengetahuan siswa yang memiliki konteks aplikasi yang terbatas).

Penelitian ini mengkaji learning obstacle dari beberapa faktor tersebut. Faktor didaktis didapat dari wawancara guru mata pelajaran matematika dan kajian RPP guru mata pelajaran, sedangkan faktor epistemologis didapat dari tes diagnostik dan wawancara guru mata pelajaran matematika.

Untuk mengidentifikasi learning obstacle pada penelitian ini dilakukan dengan 3 cara: 1) melakukan tes diagnostik: tes diagnostik dilakukan di kelas IX SMP Shailendra Palembang, tes diagnostik berpanduan dengan buku tes diagnostik Departemen Pendidikan Indonesia tahun 2007, 2) wawancara dengan guru mata pelajaran: dilakukan dengan seorang guru dengan jenis wawancara adalah wawancara baku terbuka dengan berdasarkan pedoman wawancara, dan 3) kajian RPP guru: kajian RPP guru ini dilakukan sendiri dan para ahli yang berkompeten di bidangnya, dengan lembar validasi yang bersumber pedoman praktik pengalaman lapangan program PPG dalam jabatan Universitas PGRI Palembang tahun 2019.

Teknik analisis data pada penelitian ini dengan menggunakan metode perbandingan tetap atau Constant Comparative Method.

1. Analisis data: (a) Identifikasi satuan (unit). Awalnya diidentifikasikan adanya satuan yaitu bagian terkecil yang ditemukan dalam data yang memiliki makna bila dikaitkan dengan fokus dan masalah penelitian, identifikasi ini dilakukan pada saat wawancara dengan guru mata pelajaran, identifikasi learning obstacle, analisis tes materi prasyarat, analisis tes identifikasi akhir dan menganalisis rekaman video. Pada saat reduksi data inilah terjadi penghapusan kode untuk learning obstacle pada tes diagnostik pada nomor 2D, karena hampir seluruh siswa tidak menjawab soal tersebut. (b) Sesudah satuan diperoleh, langkah berikutnya adalah membuat koding. Membuat koding berarti memberikan kode pada setiap 'satuan', supaya tetap dapat ditelusuri data/satuannya, berasal dari sumber mana.

2. Kategorisasi: (a) Menyusun kategori. Kategorisasi adalah upaya memilah-milah setiap satuan ke dalam bagian-bagian yang memiliki kesamaan, pengategorian ini dilakukan pada saat identifikasi Learning obstacle dan analisis tes materi prasyarat yang terjadi pada siswa. (b) Setiap kategori diberi nama yang disebut 'label'.

3. Sintesisasi: (a) Mensintesiskan berarti mencari kaitan antara satu kategori dengan kategori lainnya, kaitkan di sini adalah mengkaitkan antara hasil dari 
identifikasi learning obstacle dengan hasil wawancara guru mata pelajaran. (b)

Kaitan satu kategori dengan kategori lainnya diberi nama/label lagi.

Menyusun 'Hipotesis Kerja': Hipotesis kerja ini sudah merupakan teori substantif (yaitu teori yang berasal dan masih berkaitan dengan data). Inti analisis kualitatif terletak pada tiga proses yang berkaitan yaitu: mendeskripsikan fenomena, mengklasifikasikannya, dan melihat bagaimana konsep-konsep yang muncul itu satu dengan lainnya berkaitan. Proses tersebut dalam penelitian ini merupakan proses metapedadidaktik, proses ini untuk menunjukkan antara siswa, guru, dan materi mempunyai kaitan satu dengan lainnya (Moleong, 2018).

\section{HASIL DAN PEMBAHASAN}

Identifikasi learning obstcale pada penelitian ini didapat dari hasil analisis tes diagnostik, hasil wawancara guru dan hasil kajian RPP guru. Tes diagnostik ini dilakukan pada kelas IX SMP Shailendra Palembang yang berjumlah 27 siswa yang mengikuti tes diagnostik, akan tetapi pada saat tes ini dilakukan terdapat seorang siswa yang tidak masuk sekolah sehingga yang mengikuti tes diagnostik berjumlah 26 siswa. Tes ini dilakukan di kelas IX karena kelas VIII dan kelas IX terdapat pada sekolah yang sama yaitu SMP Shailendra Palembang kemudian memakai kurikulum yang sama yaitu KTSP 2006 dan juga mempunyai guru mata pelajaran matematika yang sama, jadi bisa diasumsikan mempunyai karakterisrik yang sama.

Tes diagnostik ini dilakukan untuk mengetahui konsep prasyarat yang menjadi learning obstacle pada materi volume limas. Sejalan dengan Tanzimah dkk (2013) untuk mempelajari suatu konsep yang berdasarkan pada konsep lain, seseorang perlu memahami lebih dahulu konsep prasyarat tertentu, tanpa memahami konsep prasyarat tersebut tidak mungkin orang itu memahami konsep barunya dengan baik.

Aspek yang dilihat dari tes diagnostik pada penelitian ini adalah:

1) Menyelesaikan keliling dan luas bangun segitiga dan segiempat

2) Menghitung salah satu panjang sisi segitiga siku-siku dengan menggunakan dalil phytagoras

3) Menghitung volume kubus

4) Menemukan rumus volume limas

5) Menentukan rumus volume limas jika diketahui keliling alas limas

6) Menyelesaikan masalah sehari-hari

Berikut ini adalah hasil analisis tes diagnostik siswa:

Tabel 1. Analisis hasil tes diagnostik

\begin{tabular}{clcc}
\hline \multirow{2}{*}{ No } & \multicolumn{1}{c}{ Temuan learning obstacle } & \multicolumn{2}{c}{ Persentase kesalahan } \\
\cline { 3 - 4 } & \multicolumn{1}{c}{$\begin{array}{c}\text { Mampu mengidentifikasi apa yang diketahui dalam masalah } \\
\text { menggunakan argumen Pythagoras tetapi salah dalam } \\
\text { menggunakan konsep Pythagoras }\end{array}$} & $89 \%$ & \\
2 & $\begin{array}{l}\text { Mampu mengidentifikasi apa yang diketahui dalam masalah } \\
\text { menggunakan argumen Pythagoras tetapi salah dalam }\end{array}$ & $44 \%$ & $74 \%$ \\
menggunakan konsep Pythagoras & $\begin{array}{l}3 \text { Kesalahan dalam formula volume dan menentukan } \\
\text { volume piramida karena sifat dan karakteristik piramida } \\
\text { Tidak memberikan jawaban }\end{array}$ & $70 \%$ \\
\hline
\end{tabular}


Dilihat dari hasil analisis tes diagnostik pada tabel 1 didapat learning obstacle pada konsep phytagoras, terlihat dari jawaban yang dibuat oleh siswa. 1) Siswa yang mengalami kesulitan pada konsep phytagoras juga mengalami kesulitan pada konsep perpangkatan sejalan dengan penelitian yang dilakukan oleh Tuzahrah, Rasiman, dan Ijuddin (2016) yang menganalisis kesulitan pada konsep perpangkatan, hasil dari analisis kesulitan belajar menunjukkan bahwa siswa mengalami kesulitan pada tahap konsep, prinsip, dan operasi hitung. Jadi diputuskan bahwa konsep perpangkatan termasuk di dalam learning obstcale yang dihadapi siswa. 2) Dilihat dari hasil analisis tes diagnostik menunjukkan siswa mengalami kesulitan pada konsep satuan luas dan volume pada setiap nomor soal. Jadi disimpulkan bahwa siswa tersebut juga mengalami kesulitan pada konsep satuan luas dan volume.

Hasil analisis tes diagnostik juga mengalami reduksi data seperti soal nomor 2D, soal nomor 2D dihapuskan disebabkan oleh hampir seluruh siswa tidak menjawab soal tersebut. Hal ini terjadi berdasarkan kajian terhadap soal tersebut, kemungkinan soal tersebut menggunakan bahasa yang berbelit-belit sehingga sulit dimengerti siswa.

Dari aspek yang dilihat pada tes diagnostik, didapatkan hasil dari tes diagnostik tersebut yaitu sebagai berikut:

1. Learning obstacle pada konsep phytagoras

2. Learning obstacle pada konsep satuan luas dan volume

3. Learning obstacle pada konsep limas

Dari hasil analisis tes diagnostik, berikut ini contoh beberapa jawaban siswa yang dominan menjadi learning obstacle yang dihadapi siswa:

1. Kejadian LO.D1A.1

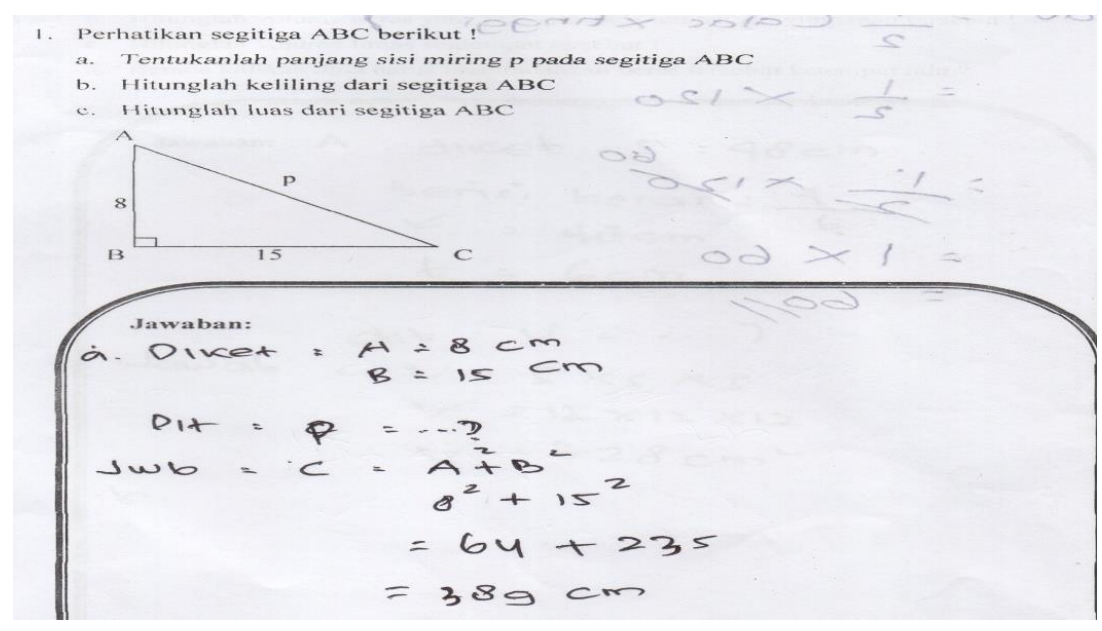

Gambar 2. Lembar jawaban siswa pada kejadian LO.D1A.1

Dari Gambar 2 terlihat siswa belum mampu dalam menuliskan rumus phytagoras, salah dalam konsep perpangkatan dan salah dalam penjumlahan. 
2. Kejadian LO.D2C.

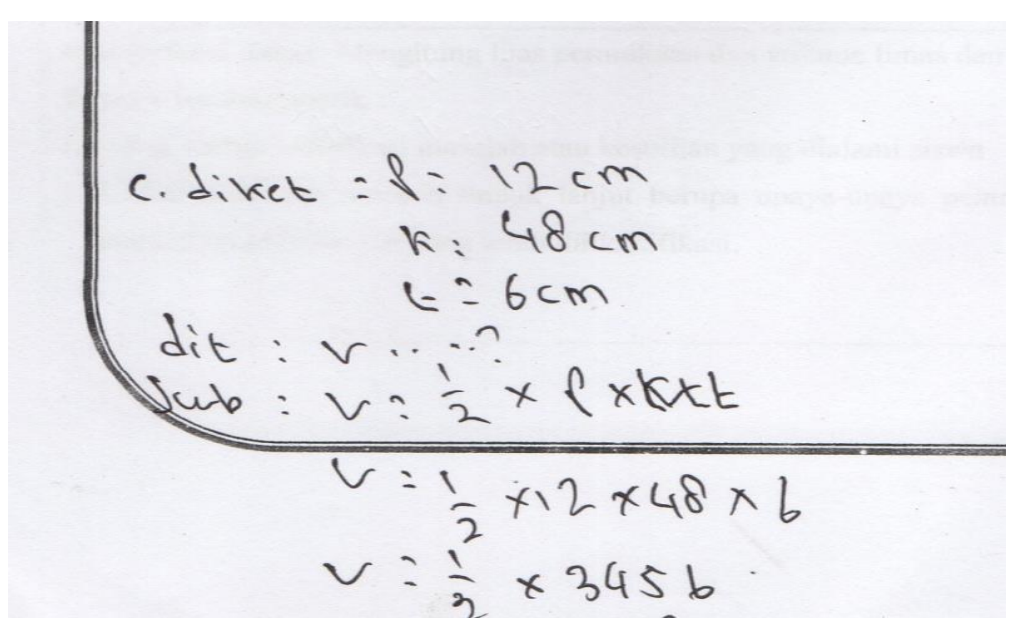

Gambar 3. Lembar jawaban siswa pada kejadian LO.D2C.2

Dari Gambar 3 terlihat siswa kurang tepat dalam menuliskan rumus dan salah sehingga salah dalam menjawab soal, kemudian siswa tersebut tidak menuliskan satuan yang tepat.

1) Analisis learning obstacle dari hasil wawancara dengan guru mata pelajaran berpedoman dengan pedoman wawancara.

Jenis wawancara pada penelitian ini adalah wawancara baku terbuka dan berdasarkan pedoman wawancara. Berikut adalah pertanyaan dan jawaban dari wawancara yang dilakukan terhadap guru mata pelajaran.

Tabel 2. Pertanyaan dan jawaban wawancara guru

\begin{tabular}{|c|c|}
\hline Pertanyaan & Jawaban \\
\hline $\begin{array}{l}\text { Kesulitan yang dialami siswa di saat } \\
\text { berlangsungnya belajar-mengajar? }\end{array}$ & $\begin{array}{l}\text { Kurangnya bahan ajar dan belum } \\
\text { memahami matri-materi sebelumnya }\end{array}$ \\
\hline $\begin{array}{l}\text { Faktor yang mempengaruhi kesulitan } \\
\text { itu terjadi? }\end{array}$ & $\begin{array}{l}\text { Kurangnya buku paket dan kurang } \\
\text { konsentrasi }\end{array}$ \\
\hline $\begin{array}{l}\text { Reaksi siswa ketika tidak mengerti } \\
\text { materi yang disampaikan? }\end{array}$ & $\begin{array}{l}\text { Bingung, malas memperhatikan, dan } \\
\text { mengerjakan soal }\end{array}$ \\
\hline $\begin{array}{l}\text { Apakah siswa menyukai pelajaran } \\
\text { matematika? }\end{array}$ & $\begin{array}{l}\text { Sebagian besar tidak menyukai } \\
\text { matematika }\end{array}$ \\
\hline Metode apa yang digunakan? & $\begin{array}{l}\text { Ceramah, tanya jawab, diskusi dan } \\
\text { pemberian soal }\end{array}$ \\
\hline $\begin{array}{l}\text { Bagaimana respon dengan metode } \\
\text { yang digunakan? }\end{array}$ & $\begin{array}{l}\text { Sebagian besar menyukai metode } \\
\text { diskusi }\end{array}$ \\
\hline Bagaimana hasil ujian yang diadakan? & Kurang memuaskan \\
\hline $\begin{array}{l}\text { Upaya yang ditempuh untuk } \\
\text { mengatasi kesulitan? }\end{array}$ & Pemberian soal latihan dan tanya jawab \\
\hline
\end{tabular}


Dari pertanyaan dan jawaban dari wawancara di atas didapat hasil analisis learning obstacle dari wawancara dengan mata pelajaran:

1. Kurangnya bahan ajar

2. Siswa belum memahami materi-materi sebelumnya seperti lupa

Learning obstacle tersebut didapat dari wawancara dengan guru mata pelajaran yang mengajar di kelas VIII SMP Shailendra Palembang.

2) Selanjutnya analisis learning obstacle dari hasil kajian RPP guru mata pelajaran matematika yang dilakukan sendiri dan dibantu ahli yang berkompeten pada bidangnya

Kajian RPP guru pada penelitian ini adalah kajian RPP guru mata pelajaran matematika pada kelas VIII SMP Shailendra Palembang pada materi volume limas. Kajian RPP guru mata pelajaran matematika ini untuk melihat aktifitas pembelajaran yang dilakukan oleh guru di saat mengajar materi volume limas di kelas VIII Shailendra Palembang. Kajian RPP dilakukan sendiri dan dibantu para ahli yang berkompeten di bidangnya dengan lembar validasi yang bersumber dari pedoman praktik pengalaman lapangan program PPG dalam jabatan Universitas PGRI Palembang tahun 2019.

Tabel 3. Aspek yang dikaji pada RRP guru mata pelajaran

\begin{tabular}{|c|c|c|}
\hline No & $\begin{array}{c}\text { Aspek yang dikaji pada RPP guru } \\
\text { mata pelajaran }\end{array}$ & $\begin{array}{c}\text { Hasil analisis RPP guru mata pelajaran } \\
\text { sesuai aspek yang dilihat }\end{array}$ \\
\hline 1. & Identitas mata pelajaran & Kesesuaian identitas mata pelajaran \\
\hline 2. & Perumusan indikator & Tidak adanya perumusan indikator \\
\hline 3. & Perumusan tujuan pembelajaran & $\begin{array}{l}\text { Ketidaksesuaian perumusan tujuan } \\
\text { pembelajaran }\end{array}$ \\
\hline 4. & Pemilihan materi ajar & Ketidaksesuaian pemilihan materi ajar \\
\hline 5. & Pemilihan sumber belajar & Tidak adanya pemilihan sumber belajar \\
\hline 6. & $\begin{array}{l}\text { Pemilihan media pembelajaran, } \\
\text { metode/pendekatan/metode } \\
\text { pembelajaran }\end{array}$ & $\begin{array}{l}\text { Tidak adanya pemilihan media } \\
\text { pembelajaran, metode/pendekatan/metode } \\
\text { pembelajaran }\end{array}$ \\
\hline 7. & Prosedur pembelajaran & Ketidaksesuaian prosedur pembelajaran \\
\hline 8. & Rancangan penelitian pembelajaran & $\begin{array}{l}\text { Ketidaksesuaian rancangan penelitian } \\
\text { pembelajaran }\end{array}$ \\
\hline 9. & $\begin{array}{l}\text { Rancangan tindak lanjut hasil } \\
\text { penelitian }\end{array}$ & $\begin{array}{l}\text { Tidak adanya rancangan tindak lanjut } \\
\text { hasil penelitian }\end{array}$ \\
\hline
\end{tabular}

Dari tabel 3 hasil kajian RPP guru didapat kesimpulan masih kurang sempurna RPP guru yang digunakan sebagai pedoman mengajar.

Sedapat mungkin dihindari dibuatnya sub-sub judul, mesti diatur bagaimana sub judul tersebut dapat membaur dan menyatu di dalam teks. Jika memang ada subjudul, maka subjudulnya dibuat bold dan hanya huruf depannya saja yang kapital.

\section{SIMPULAN DAN SARAN}

Learning obstacle pada materi volume limas dari faktor epistemologis adalah sebagai berikut: (a) Learning obstacle pada konsep perpangkatan; (b) Learning obstacle pada konsep phytagoras; (c) Learning obstacle pada konsep satuan luas dan volume; dan (d) Learning obstacle pada konsep limas. Learning obstacle pada 
materi volume limas dari faktor didaktis adalah RPP guru mata pelajaran tidak mencerminkan kegiatan belajar-mengajar yang cocok untuk materi volume limas. Learning obstacle pada materi volume limas dari faktor ontogenik tidak ditemukan pada saat berlangsungnya proses penelitian.

Penelitian ini hanya sekali dilakukan tes diagnostik, hal ini membuat data yang didapat mengenai learning obstacle tidak secara menyeluruh. Oleh karena itu perlu diadakannya penelitian konfirmasi untuk melihat learning obstacle pada materi volume limas.

\section{DAFTAR PUSTAKA}

Blanco, L. J. 2001. Errors in The Teaching/learning of The Basic Concepts of Geometry. International Journal For Mathematics Teaching And Learning, 24.

Brousseau. 2002. Theory of Didactical Situation in Mathematics. The Netherlands: Kluwer Academic Publishers.

Cahyaningrum, S. 2015. Identifikasi Kesulitan dalam Menyelesaikan Soal Cerita Pokok Bahasan Prisma dan Limas Siswa Kelas VIII Semester II SMP Negeri 4 Delanggu Tahun Ajaran 2014/2015. Disertasi tidak dipublikasikan. Universitas Muhammadiyah Surakarta.

Fauziah, N. S. 2016. Desain Didaktis Konsep Pangkar dan Akar Berdasarkan Learning Obstacle dan Learning Tajectory. [Online]. Tersedia : http://repository.upi.edu/29916/

Fuadiah, N. F., Suryadi, D., dan Turmudi, T. 2017. Some Difficulties in Understanding Negative Numbers Faced by Students: A Qualitative Study Applied at Secondary Schools in Indonesia. International Education Studies, Vol. 10(1) : 24-38.

Fuadiah, N. F., Suryadi, D., dan Turmudi, T. 2019. Teaching and Learning Activities in Classroom and Their Impact on Student Misunderstanding: A Case Study on Negative Integers. International Journal of Intruction, Vol. 12(1) : 407-424.

Istiani, A. dan Hidayatulloh. 2017. Analisis Kesalahan Siswa dalam Menyelesaikan Soal Pada Materi Bangun Ruang Sisi Datar. Makalah Pada Prosiding Seminar Nasional Matematika dan Pendidikan Matematika Universitas Islam Negeri Raden Intan, Lampung, 6 Mei 2017. Hal: 129-135.

Moleong, 1.J. 2018. Metodologi Penelitian Kualitatif. Bandung: PT Remaja Rosdakarya.

Mudzakir, A. S. 2010. Penulisan Buku Teks yang Berkualitas. Bandung: Pustaka.

Program PPG dalam Jabatan. 2019. Pedoman Praktik Pengalaman Lapangan. Palembang: Universitas PGRI Palembang.

Risnanosanti. 2012. Hypothetical Learning Trajectory Untuk Menumbuhkembangkan Kemampuan Berpikir Kreatif Matematis Siswa SMA di Kota Bengkulu. Makalah Pada Prosiding Seminar Nasional Matematika dan Pendidikan Matematika Universitas Negeri Yogyakarta. Hal: 743-750. ISSN 978-979-16353-8-7.

Sarah, S., Suryadi, D., dan Fatimah, S. 2017. Desain Didaktis Konsep Volume Limas Pada Pembelajaran Matematika SMP Berdasarkan Learning Trajectory. Jurnal Pendidikan Matematika Indonesia, Vol. 1(1) : 31-42. 
Sholihah, S.Z. dan Afriansyah, E.A. 2017. Analisis Kesulitan Siswa dalam Proses Pemecahan Masalah Geometri Berdasarkan Tahapan Berpikir Van Hiele. Mosharafa, Vol. 6(2) : 287-298.

Sunarsi, A. 2009. Analisis Kesalahan dalam Menyelesaikan Soal Pada Materi Luas Permukaaan serta Volume Prisma dan Limas Pada Siswa Kelas VIII Semester Genap SMP Negeri 2 Karanganyar Tahun Ajaran 2008/2009. Skripsi tidak diterbitkan. Surakarta: Universitas Sebelas Maret.

Suryadi, D. 2013. Didactical Design Research (DDR) dalam Pengembangan Pembelajaran Matematika. Makalah Pada Prosiding Seminar Nasional Matematika dan Pendidikan Matematika Universitas Pendidikan Indonesia. Vol. 1 : 3-12. ISSN 977-2338831.

Suryadi, D. 2016. Didactical Design Research (DDR) : Upaya Membangun Kemandirian Berpikir Melalui Penelitian Pembelajaran. Makalah Pada Seminar Nasional Matematika dan Pendidikan Matematika Program Studi Pendidikan Matematika FKIP UNSWAGATI, Cirebon, 6 Februari 2016. ISBN 978-602-71252-1-6.

Tanzimah, Somakim, dan Santoso, B. 2013. Desain Pembelajaran Operasi Penjumlahan dan Pengurangan Bilangan Bulat Menggunakan Media Permainan Kakisambe di Kelas IV Sekolah Dasar. Jurnal Sekolah Dasar, Vol. 22(2) : 112-121.

Tuzahrah, F., Rasiman, Z., dan Ijuddin, R. 2016. Analisis Kesulitan Belajar Siswa dalam Menyelesaikan Soal Bilangan Berpangkat di Kelas X SMA. Jurnal Pendidikan dan Pembelajaran Khatulistiwa, Vol. 5(10) : 1-12.

Yunarti, T. 2017. Desain Didaktis Berbasis Masalah; Untuk Teori Peluang SMA, Pendekatan Baru Dalam Memperbaiki Pembelajaran Matematika. Bandar Lampung: Media Akademi. 